\title{
Greek Economic Crisis and Changes in HR Management The Case of Greek Structural Design Engineers
}

\author{
George Xanthakis \\ Aegean University, Department of Business Administration, Chios, Greece \\ E-mail: xanthakisg@gmail.com
}

Received: April 6, 2020 Accepted: April 30, 2020 Online published: May 18, 2020

doi:10.5296/ijhrs.v10i2.17054 URL: https://doi.org/10.5296/ijhrs.v10i2.17054

\begin{abstract}
Nowadays the modern business operates in an ever-changing environment that is strongly influenced by technological, political, social, economic and scientific developments. Its future and success are based on its ability to manage properly and to develop its human resources that are the most important and at the same time the most difficult resource.

Because of the economic crisis that started on 2008 the work environment worldwide changed in a great number of organizations. This sudden change of organization generated new topics in the field of organizations. Leadership and motivation in the workplace are two of them.

The current work paper focuses on the in-depth analysis of a small group of employees (qualitative research) in a workplace with a strong influence from the Greek economic crisis, although in the last years was one of the main sectors of the economy.

In the first part is presented the social and working face of Greece, the timeline of Greek crisis and its consequences. An empirical research conducted within the changing environmenent, its results, conclusions and recommendations complete the current paper. The outcome highlights the need of Great leadership, communication and inside motivation within the economic crisis environment.
\end{abstract}

Keywords: Greece, economic crisis, motivation, leadership, qualitative research, Greek crisis-HRM changes

\section{Intro-social and Working Face of Greece}

Greece is an aging country (Balourdos, 2013) with a low birth rate. Young Greeks leave their parents' home around thirty shortly before they set up their own family. Greece in 2009 had the largest number of students in Europe, in proportion to its population size, in Greek 
universities and in Europe. Greece is a major "exporter" of students in Europe, although it holds one of the higher unemployment rates among young people and in Europe.

Greece remains a relatively traditional society about the formation of family and family structure. Pairs marry and acquire children within marriage, while the percentage of single-parent families in Greece is very low. Most Greeks live in their own homes and the usual phenomenon for the Greek society is the provision of the parents to the children of their first residence. The model of the family where both parents work is common, while the traditional Greek family supports its members replacing the (sometimes non-existent) Provident State.

The usual form of employment in Greece is permanent work, while the type of part-time work is small. Most employees are employed in the service sector (around 70\%), followed by the production sector (around 20\%). More than one third of all Greek population are self-employed. The above population is a relatively heterogeneous group of farmers, shop owners, other traders, self-employed and members of the liberal professions (law, medicine and engineers.

According to surveys (OECD, 2010), Greeks work long hours, but their profitability is low compared to the other European countries. At the same time, they appear to have several bank liabilities which characterize them as heavily indebted (Figure 1).

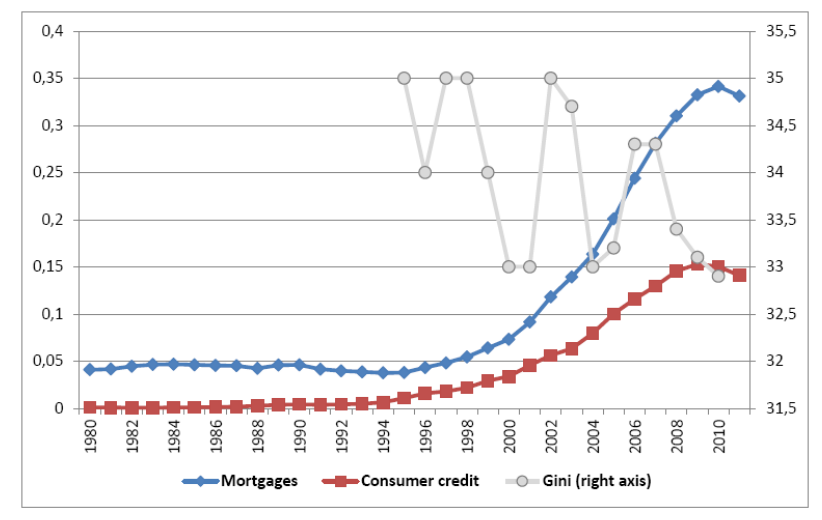

Figure 1. Financial obligations as percentage of GDP

Source: Greek Statistic Service

The construction sector, which includes private construction and public works (co-financed by the European Union or not), has been one of the most dynamic sectors of the Greek economy, accounting for about $8 \%$ of GDP, while all employees in building construction accounts for $9 \%$ of the country's total workforce.

Between 1998 and 2007, the construction sector experienced the fastest growth in the economy. The international financial crisis has found the construction sector in the country in a negative way, as problems in the field of public works and private works were already diagnosed in 2007 and 2008. The international financial crisis has affected business expectations and has greatly reduced the financial liquidity of individuals and businesses. 


\section{The Timeline of Greek Crisis}

Until 1974 (Stathakis, 2008) and after a long period of economic development that began in the mid-1950s and lasted for 20 years, the Greek economy was based on a relatively low state budget. Public spending, maintaining a moderate public sector, covering high military spending and a welfare state at a very basic level, constituted about $25 \%$ of GDP for about three decades. However, the state machine had a central role in the economy, through the widespread governmental ownership and control in key areas (banks, energy, telecommunications and infrastructure).

The persistent trade deficit was funded by earnings from profitable merchant shipping. The rapid growth rates have been sustained and sustained by a combination of foreign and domestic investment in industry, modernization of agriculture and public investment in infrastructure. The mass urbanization of this period was associated with an impressive growth in the construction sector.

The tax system was based on indirect taxation, i.e. consumption taxes and other income. Income taxes were mainly borrowed by employees. Typically, business activities contributed less than $10 \%$ of tax revenue. Farmers, who constituted a large proportion of the population (about 50\%), were excluded from direct taxation. The industry sector, which received state subsidies, enjoyed favourable tax arrangements.

Thus, the policy of "economic growth at any cost" was combined with a system of tax adjustments linked to the financial system, which included a peculiar kind of "social compromise". The state machine supported a number of sectors, while in return for others it allowed a "tax evasion" rate. Employees paid a small income tax plus excise taxes. The tax system was "anti-progressive" since it had no redistributive function of wealth. The issue of social equality has been sacrificed on the back of economic growth. Also, Greek governments showed little care for social issues.

In 1973, inflation was relatively low, and the drachma was a volatile currency. Democracy went to Greece in 1974, and the state began to grow. Initially, nationalization of private enterprises (including aviation, shipbuilding, part of the private banking sector).

The state expansion ceased in 1981, bringing the socialists to the forefront, who in turn had to cope with over-indebted state-owned enterprises, some of which were closed, while others were gradually being privately exploited by the end of the $1990 \mathrm{~s}$.

Public expenditures began to increase in 1979 but expanded during the 1980s. In 1989 public spending accounted for about $40 \%$ of GDP, while in 1995 they climbed to 55\%, with social benefits accounting for a large proportion of them.

During the 80 's the inflation was high (20-25\%), the drachma was depreciated several times and the economy in crisis. The tourism industry was on the rise, as was the agriculture sector, which was "winning" European subsidies with farmer income to improve significantly, but the boom of imports undermined a significant part of the profits.

The expansion of the public sector was covered by national loans and the Greek public debt 
was born, which grew at a very high rate (around 10\% per annum) in the 1980s.

Tax revenues are not rising at the same pace as public spending, resulting in an increase in the deficit. The necessary tax adjustment has never taken place and indirect taxes have remained the main source of taxation. The introduction of value added tax, imposed by European legislation, has helped rationalize the system of excise duties and stabilize it as the main source of tax revenue.

According to Matsaganis (2010), "direct taxes continued to be paid only by employees, while in fact the vast majority of the wealthy strata of Greek society continued to pay symbolic taxes." This category also includes all kinds of businesses, banks, commercial companies, construction companies as well as a number of self-employed (lawyers, engineers, doctors, craftsmen, etc.). Under these circumstances, " $20 \%$ of the richest part of the population was tax evasive, with mathematical precision in deadlock. Tax revenues are in the range of $30-35 \%$ of GDP, while public spending is at 40-45\% of GDP. The budget deficit in 1994 had reached a record high of 15\% of GDP" (Matsaganis, 2010).

Until the mid-1990s, the Greek economy was in a 'period of gradual adaptation and change'. Budgetary adjustment and monetary stabilization have become the priority objectives of economic policy (Pagoulatos, 2003). Initial privatizations, (first the banking system) and then the liberalization of the foreign capital market have attempted to attract business investment and bring and economic growth.

Inflation is declining due to the "hard drachma" policy, while tourism, shipping, banking, telecommunications and construction are the industries that have attracted the greatest investment. The comparative advantage was evident in the case of tourism and shipping. Also significant is the expansion of Greek businesses in the Balkans, Central and Eastern Europe.

This new economic structure had significant similarities to older models of the Greek economy, where the economy was based on a combination of a high percentage of services and a small percentage of industrial production. The euro has been an important step towards the internationalization of Greek capital.

However, this orientation of the economy has had a negative impact on the productive sectors of the economy, such as agriculture and manufacturing. In general, the agricultural sector entered a period of contraction and decline until 2000 and absolute decline afterwards. The industry was already in a permanent state of decline. Agricultural and industrial exports account for just $10 \%$ of GDP, while tourism adds another $10 \%$ and revenue from shipping $10 \%$ extra. Imports have increased to $40 \%$ of GDP, resulting in a permanent deficit (around $10 \%$ ) in the balance of payments, which was usually financed by national loans, subsidies and other secondary sources.

This new orientation of the Greek economy has been preserved and maintained by the mass influx of immigrants from Albania, the Balkans, Eastern Europe and the Arab world. About one million foreign workers provide cheap workforce in construction, tourism and manufacturing. While at the same time foreign workers have stimulated the branch of decadent agriculture. The result of this labour invasion is the increase from 3.3 to 4.2 million 
over a decade.

As the new structure of the economy favored large companies, the form of wage labor prevailed. The Greek economy, traditionally identified with small-scale family businesses, is gradually turning into a more formal European economy with $65 \%$ of employment being employed.

As family businesses faced difficulties, employment in the public sector became more attractive to new generations, who had the strength of university education. In the private sector, there is a new framework of low wages and flexible forms of employment. Unemployment, following in other economies.

When the global financial crisis of 2008 began, he found the Greek economy in decomposition state. In 2009, the fiscal crisis was transformed into a very short time in a sovereign debt crisis, which eventually evolved into a deep and prolonged recession. By the end of 2013 , the size of the economy has shrunk by $23.5 \%$ compared to 2007 , much higher than the corresponding prices in other southern European economies over the same period. The Greek economy introduced a recession unprecedented in economic world history in a time of peace.

\section{Impact of Economic Crisis}

Because of the impact of the economic crisis and the high and still rising unemployment rates, there is a significant fall in happiness levels (wellbeing). The tough austerity program involves cutting public spending, phasing out subsidies (e.g. health, education), freezing wages in the public sector, reducing pensions, postponing social benefits, tough taxation. The above crisis results in several negative social and economic consequences. The main ones are summarized in the vicious circle of recession, unemployment, stifling pressure on the lower and middle class, the rise in homelessness, desperate citizens, the number suicide and the deterioration of public health.

There is no doubt that the feature in the current crisis is the rising unemployment. In May 2013, the number of unemployed was almost 1.4 million, with an unemployment rate of $27.5 \%$. Permanent employment (a common form of work in Greece) has declined in recent years, while part-time work has increased significantly. In the self-employed sector, a large number of businesses were closed, resulting in many jobs being lost. What is unknown is the number of self-employed workers who seem to have a job, even if their net income is zero. A typical case of engineers, who have been left with little or no work activity due to the great crisis in the construction sector. Job losses have reached an abnormally high number, while the loss of income for those who are still working is significant.

Due to the impact of the economic crisis and the high and constantly increasing unemployment rates, there is a significant fall in the levels of poverty in Greece and a reduction in the well-being. The austerity program includes reduction of the Public Sector expenses and wages, gradual elimination of various subsidies (health, education) and social welfare payments, harsh taxation and pension cuts. 
The above situation has a series of negative social and economic impacts on the society. The principal ones are the vicious circle of recession, the pressure on the middle social class, the rise of the homeless, the increase of desperate people and the deterioration of public health (Markovits, 2008).

The impact of the crisis on jobs was different in each workplace. More jobs were lost to industry than to services, while employment in agriculture looks to have come to a limit. As far as professional gradation is concerned, the crisis seems to have altered the composition of the workforce. Directors, technicians and related professions, account for more than $50 \%$ of total employment decline. Qualified and semi-skilled workers in manual occupations also experienced significant job losses. Permanent employment (the common form of work in Greece) has declined in recent years, while part-time work has increased. In 2012, $10 \%$ of all workers in Greece were on fixed-term contracts and $7.7 \%$ a hundred of them worked part-time, compared with $13.8 \%$ and $23.1 \%$, respectively, in the European Union. The above data does not include non-standardized forms of self-employment considered as self-employed. (Matzaganis, 2013).

More than one third of the total Greek workers are self-employed, the highest percentage in the European Union. The above population is a relatively heterogeneous group, consisting of farmers with often small land plots, shop owners, other traders, self-employed and members of the freelance professions (law, medicine and engineers). Above group also include an unknown number of employees who provide dependent work that translates into self-employment by providing services to a single provider in a continuous manner, hence acting as employees (OECD 2010). In the self-employed sector, a large number of businesses were closed, resulting in job losses. At this point, it would be useful to point out that an unknown number of self-employed seem to hold a job, even if the business is their net income is zero. This is a case of engineers who have been left with little or no job activity due to the great crisis in the construction sector (Stathakis, 2008).

While job losses have reached an abnormally high number, on the other hand the loss of income for those who are still working is also important (Tsekos, 2015). The average real gross earnings of workers have lost more ground since the beginning of the crisis than it was acquired over the nine years prior to that. In particular, having increased by $23 \%$ in the period 2000-2009, in 2013 the average earnings had fallen below the 2000 level by $9 \%$. Overall, a decline in earnings over the period 2009-2013 was over 26\% on average (gross earnings). The increasing tax pressure has brought the above loss even more pronounced in clean terms. Profit from self-employment also declined, but in this case reliable estimates are difficult to record. Note that the above applies to the official sector of the economy. In the so-called informal sector (part of the construction industry, agriculture, tourism and other services), where employers are subject to fewer restrictions, the losses are more (OECD, 2010).

\section{Empirical Research - Methodology}

During the period 2008-2017 the working environment in Greece changed dramatically. When times change and society is in crisis the human Resources has a crash test. During this storm motivation in work place caught our eyes. 


\section{Mll Macrothink}

International Journal of Human Resource Studies

ISSN 2162-3058

2020, Vol. 10, No. 2

The subject we are examining and focusing is on the wider field of HR management, leadership- employee's motivation and especially in conditions of economic crisis. The research focused on a specific professional team: the Structural Design Engineers and in especially those who work with a dependent employment within a firm. The current research attempted to investigate the impact of economic crisis on the motivation factors in the working environment.

The chosen research methodology is the combination of two methods: the case study and the construvistic grounded theory (Charmaz 2000, 2006). The placement of this research in the existing research framework and the existing theoretical approaches (as analysed in next section) led the authors to adopt the dynamic view of motivation in which the importance and the placement of the employee's needs are different for each and quite subjective. In order to introduce the diversity of each employee's needs into our research, we consider, as independent variables (and later thematic units), the particular employee characteristics that highlighted during the interviews. The qualitative method used in the empirical research as it agrees with the objective of this research, the deep understanding, exploring and interpreting the personal perceptions, beliefs and experiences of participants about motivation factors in the workplace.

Interviews and their evaluation by grounded theory (Glaser \& Strauss, 1967) were used as a methodology for the empirical part of the paper. Interviews enable us to capture ideas of respondent without biasing them by our own ideas. Grounded theory is a systematic methodology that enables to search for and conceptualize social patterns and structures. It is based on collection of qualitative data in which repeated ideas, concepts and structures are searched for. Grounded theory may lead to identification of new concepts and theories. The collection of data was done by a qualitative research via semi- structured interviews.

The current research explored the employee's motivation considering a dynamic environment, taking into account:

- the specific characteristics of the target population and the its working environment (Greek labor market),

- the work identity of each employee (sample-case studies),

- as well as the socio-economic context in which the research was conducted (economic crisis).

In order to achieve this, a qualitative survey of twelve personal semi-structured interviews was conducted, that led to the creation of equal number case studies. Through that personal interviews explored:

- the social and working image of each employee,

- the needs of the employees,

- behaviors and factors that influence and shape them,

- thoughts (alternatives) about the future and the next steps, 
- motivation factors before and during the crisis,

- how the employees perceive the management actions and how they comment on the capabilities of the Company's Management.

Even though grounded theory approach is more complicated in evaluation, the authors decided for it as they aimed to capture the reality as it is without influencing respondents by guidelines and their own mental images.

\subsection{Greek Labor Market}

The Greek labor market has a peculiarity compared to the labor markets and social structures of the economically developed countries of Europe and America. This particular feature consists in the existence of both a high percentage of self-employed and a very low proportion of wage earners within the economically active population (TEE, 2008). Greece is characterized by the highest percentage of self-employed $(33.1 \%)$, the lowest percentage of employees $(45.5 \%)$ compared to the average for the corresponding period in Europe, which ranged around $85 \%$.

\subsection{Target Population}

As target population was considered the Greek Structural Design (Civil) Engineers. The above-mentioned study population has the following features:

- It has been heavily affected by the financial crisis in Greece.

- In previous years the profession has promoted upward social mobility from lower to middle class.

- The job itself (interesting, with many challenges, with personal responsibility for the result and a job that requires special knowledge and skills) and the nature of work are important factors of motivation.

- It combines an employee role (permanent job, eight hours per day, one employer) with freelance characteristics.

- The employees have a high level of education (five-year studies) and most of them hold postgraduate degrees.

\subsection{Sample-Independent Variables/and Later Thematic Units}

As sample, the employees of two structural design consultancies (Company A, B) were selected in the Athens area. Company A mainly deals with private sector business/buildings (hotel units, warehouse, residences commercial developments) while company B mainly deals with infrastructure projects. Company A has a wider range of short-term design projects with smaller budgets and it is dependent on private initiative. Company B, on the other hand, is fully specialized in its section, has a small number of long duration design projects with greater budget and is fully dependent on the public sector.

In order to introduce the diversity of each employee's needs into the current research, we 
consider, as independent variables (and later thematic units), the particular work characteristics of the each employee.

\section{Motivation}

\subsection{Mapping Research Motivation}

The first attempts to understand human motivation in workplace was that of Frederick Taylor (1911) and that of Elton Mayo (1933). Later, during 1950's and 1960's a great number of motivation theories (Maslow, Herzberg, Vroom, Adam, etc.) developed especially in USA. These theories reflect cultural and economic environment of that time, that it was a period of economic growth.

The systematic review of existing literature highlights the different approaches to motivation in the workplace. After carefully studying the research work on motivation and related theories, we have come to the following categorization of the theoretical approaches.

\subsubsection{Motivation Theories (Content vs. Process Theories)}

Content theories of motivation are based on the assumption that all people have a similar set of (unchanged) human needs and behave to meet these needs. Meeting these needs is a motivation factor. At the other hand Process theories consider that the behavior of the employees is determined and shaped by both the external environment and the individual. It is the individual who will eventually decide on how to behave and determine the intensity of the effort he will make in his work. Process theories assume that although the needs of individuals are similar, the importance and weight of them are different for the individual (dynamic view), quite subjective and leads to different behaviors.

\subsubsection{Extrinsic / Intrinsic Motivation Factors}

A large part of the literature on work motivation has been developed around the distinction between extrinsic and intrinsic motivation. The external motivation concerns the formation and maintenance of a particular behavior, linking it to specific (and desirable by the employee) benefits. Intrinsic motivation, on the other hand, results from the inner, psychological needs of the individual and their satisfaction through work (Ryan \& Deci, 2000). The behavior with intrinsic/ internal motivation is observed when there is no apparent reward other than the activity itself (Deci, 1975).

\subsubsection{The Dynamic and Multiple Character of Motivation}

Motivation in workplace is one of the most discussed subjects in organizational studies, and more generally in social sciences. As an object in direct relation to human behavior and internal psychological and cognitive processes, motivation is directly influenced by the specific environment in which each person operates (socio-economic environment-work environment). Despite the many related theories and approaches that have been developed, the many studies that have been conducted, no approach about work motivation has so far been able to offer a satisfactory holistic interpretation of the phenomenon (Latham, 2011), in order to develop a unified theory (ground theory). Hitka and Balazova (2015) point out in 
their research that motivation factors vary according to:

a) human needs

b) social conditions and lifestyle and

c) the internal and external environment of the company (Mikro-Makro environment)

\subsection{Motivation During the Economic Crisis-Literature Review}

The motivation generally at work as a subject to be studied has been explored by many scholars during the years worldwide. The uniqueness of each employee, his interaction with the working environment and the management team, the social context of each age and the changing needs of the individual in it, make it difficult to find the "absolute" motivation factors, effective for every employee. At the same time above conditions give an interest in any new work, that setting its own research framework (research sample, current socio-economic conditions) illuminates and analyzes another aspect of the "motivation" phenomenon party space.

In the 2010-2015, due to the global economic crisis, studies focus on changes in motivation factors due to this. The need for security that the employees were looking for in the workplace at the time is something that is highlighted in all studies on motivation during the crisis, mainly by the team of Hitka and Sirotiakova / 2011, / Zavadsky et al / 2015, Hitka and Balazova / (2015, Hitka et al (2015) from Slovakia and the Czech Republic. In the work of Hitka et al. (2015) states that employees enjoy the appreciation from the company and that could act as motive. Zavadski et al. (2015) proposed the interaction with the Management team as an alternative way of motivation, while communication within the organization is ranked third.

Hitka et al. (2015) report internal communication as a potential motivation factor (at no cost), that companies should not ignore. Employees are looking for support from the organization and open communication. They are looking for a leader to inspire them, and together they will go out and out of the crisis. Good relations with colleagues, good working conditions are ranked in high positions among the motivation factors during the crisis (Hitka and Sirotiakova, 2011). In Jelacic (2011, Croatia), the education factor was in the third place between the motivation factors, considering it as a professional asset for the post-crisis era. In several surveys during the economic crisis (Hitka and Sirotiakova - 2011, Hitka and Balazova - 2015, Zavadsky et al - 2015) an equity motivation factor and a fair assessment system are highlighted and discussed.

At last, I would like to refer to two surveys, which took place in Greece at about the same time, considering different target population and, have resulted in completely different results, which seem to ignore the current intense and prolonged economic crisis.

The first survey, Chatzopoulou et al. (2015) took place in the Regional Unit of Grevena (Western Macedonia) in April 2014, the sample consisted of 85 local government employees and as independent variables was used, gender, age, educational level of employees and hierarchy within the organization. 


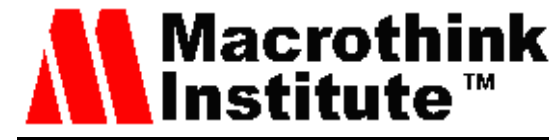

The survey concluded that in the current period of economic downturn, employees (permanent) employees in Local Government indicate as factors of motivation and satisfaction the following (in order of priority):

a) interesting work

b) equal and fair treatment,

c) objective assessment and

d) satisfactory salary

At the eleventh position shows the factor of security and stability at work.

The second research by Grammatikopoulos et al. (2013) took place in the field of mental health professionals. Four categories of health professionals (doctors, nurses, administrators, other employees) who worked in two psychiatric hospitals (Thessaloniki and Corfu) participated. The results of the study have shown the most important factors of motivation in the field:

a) meaningful work

b) respect and

c) good interpersonal relationships at the workplace

\section{Results - Motivation Factors During Economic Crisis}

This Research work explored the motivation in a dynamic environment, taking into account the socio-economic context in which the research was conducted. In order to achieve this, a qualitative research with twelve personal face to face semi-structured interviews was conducted. There are eight distinct conclusions that can be drawn in relation to the sources of work motivation.

First of them is that employees during economic crisis motivated by social aspects at work. The socialization can be with the management team and/ or with colleagues, and equal importance is placed on both kinds of socialization. The motivation factor of stability and security has been replaced by the satisfaction of the need to belong to a social / workplace.

Second factor that presented to be of importance for the motivation employed in this specific period that, namely, managers voice their appreciation towards their employees. This aspect was valued very highly, even among those women who felt like they never receive praise from their work, or whose managers simply do not show their appreciation towards their staff. This was in some cases valued even more than receiving additional compensation. The participants who had received appreciation, continued to appreciate it and acknowledge its impact on their work motivation.

Third, it is clear that the management and leadership styles that are adopted by a firm business and its management will have a determining effect on the motivation level, the morale and the job satisfaction of the employees. Nevertheless, the relationship between the 
management style that is used within the business and the level of motivation within the workforce is a subject of much debate within industry. In many circles, there is continuous debate about whether leaders are born or developed. Reflecting on the discussions about motivation, it is evident that humans are very complicated and are made up of a number of traits. With motivation, these influences are both inherited and acquired from our environment and influences It is in this regard that the study seeks to establish the role of leadership on employee motivation. The characteristics of the good boss (as a motivating factor) have been greatly modified by a "person responsible and man with knowledge and skills to solve any technical problem at work" turned into "the one who will discuss with their employees their daily problems, support and will be their link with the Management Team.

The success of every organisation depends on its employees' drive to thrive through their efforts, commitment, engagement, practice and persistence. Thus, motivation is an important topic because leadership competencies include the ability to motivate employees as one of the crucial duties or jobs. Leadership begins with the initial effort made to recruit a new employee; proceeds through the entire induction process; and continues every day until the employee departs the organisation. This process is cultivated by a manager/leader, motivating new employees and it highlights, once again, the importance of leadership to an organisation. The quality of a manager's relationship with an employee is the most powerful element of employee motivation. It creates a professional, positive and respectful attitude and employees are more likely to adopt a similar approach with their peers and enjoy work

Fourth conclusion that can be drawn is that feedback and the communication is tremendously important for employees. They tend to value the feedback received from their colleagues, managers. Feedback is also very closely related to the amount of work motivation that employee feel. Feedback indicates how they are doing their work and without indications of this work motivation is harder to achieve. The communication with the management team, the information about their plan and their schedule to deal with the crisis is a fundamental for employees and their wiring in this. The need for communication/information from management on the current situation, future actions and plans to exit the crisis has emerged as a key driver of motivation.

Fifth a form of social equality / sharing of economic losses act as a factor of motivation. The financial difficulties combined with the parallel reduction of income they face make them feel socially degraded while their employers still hold their position. Employees are looking to see the consequences of economic losses on their employers as well.

Sixth, a situation that might be easily overlooked when considering work motivation, but proved to be of significance, is simply thriving at work, good working environment. Enjoying what you do and principally enjoying going to work is something that proved to be important for achieving work motivation. It can be said that thriving at work might be a result from other aspects being "in order", but generally enjoying going to work is something that affects the overall sensation of work motivation.

Next conclusion, the potential of development was also an important element when considering work motivation. Being able to develop within the work that you do, through job 
rotation or education courses, was named as one of the primary motivators among the participants. The theoretical framework also supports the importance of personal development when trying to achieve work motivation. Therefore, the importance of possibility for development cannot be overlooked. Even though the factor continued personal development important for the employees especially those of lower hierarchy scale (younger engineers).

Finally, employees found the characteristics of the job (interesting job, personal responsibility for the result, which requires knowledge and skills and can be fulfilled from start to finish) continued to motivate the employees, to be important to have an influence on their work motivation, but their strength decreased because if the difficulties are faced during this period. Nevertheless, they were greatly appreciated and experienced as motivating to be able to influence the work. Variance/interesting job are also something that was named as a quality within work that motivates women. Not wanting to do same tasks and things day after day was strongly indicated. Job rotation, varied job tasks and - situations were named to be especially motivating. Prior research supports this notion as a key motivation factor.

Table 1. Analysing Data

\begin{tabular}{|c|c|c|}
\hline \multicolumn{3}{|c|}{ Non-Monetary Motivators } \\
\hline First Order Concept & Second Order Concept & $\begin{array}{c}\text { Core } \\
\text { Categories }\end{array}$ \\
\hline $\begin{array}{l}\text { Co-worker support and interaction } \\
\text { Time at work goes quickly and } \\
\text { creatively } \\
\text { Not anxious going to work } \\
\text { Staying at home is boring } \\
\text { Been doing the same job for years } \\
\text { Working is importance for them }\end{array}$ & $\begin{array}{c}\text { Interaction with other people } \\
\text { Happy to work } \\
\text { Importance of work }\end{array}$ & Social needs \\
\hline $\begin{array}{l}\text { Increased responsibility at work } \\
\text { Signalling appreciation } \\
\text { Full working hours } \\
\text { Be proud of your work } \\
\text { Design of known buildings }\end{array}$ & $\begin{array}{c}\text { Your effort is being noticed } \\
\text { Comments on the quality of } \\
\text { work }\end{array}$ & Appreciation \\
\hline $\begin{array}{l}\text { Co-workers feedback } \\
\text { Manager comments } \\
\text { Freedom to execute }\end{array}$ & $\begin{array}{c}\text { Comments on the quality of } \\
\text { work }\end{array}$ & \\
\hline $\begin{array}{l}\text { Looking for a confident and skilful } \\
\text { leader } \\
\text { A leader who support the employees } \\
\text { Leader with action plan } \\
\text { Leader who will inspire them } \\
\text { A leader who will analyse the } \\
\text { situation } \\
\text { and then act }\end{array}$ & $\begin{array}{c}\text { Employees looking for a leader } \\
\text { with skills, willing to lead them } \\
\text { out of the crisis }\end{array}$ & Leadership \\
\hline First Order Concept & Second Order Concept & $\begin{array}{c}\text { Core } \\
\text { Categories }\end{array}$ \\
\hline $\begin{array}{l}\text { Supportive manager } \\
\text { A manager with understanding } \\
\text { A manager who can discuss with us }\end{array}$ & Manager & \\
\hline
\end{tabular}




\section{$\triangle$ Macrothink}

International Journal of Human Resource Studies

ISSN 2162-3058

2020, Vol. 10, No. 2

\begin{tabular}{|c|c|c|}
\hline $\begin{array}{l}\text { A manager who will be our } \\
\text { connection } \\
\text { with the management team }\end{array}$ & & \\
\hline $\begin{array}{l}\text { Be informed about the future plans } \\
\text { Know what the management team } \\
\text { thinking } \\
\text { Is there any action plan? } \\
\text { What is the financial situation? } \\
\text { I want to face me honestly... }\end{array}$ & $\begin{array}{l}\text { Communication at all levels } \\
\text { Discussion with employees }\end{array}$ & Communication \\
\hline $\begin{array}{l}\text { Unequal contribution of economical } \\
\text { losses } \\
\text { They continue to lead a luxury life } \\
\text { Economic status is the same a } \\
\text { pro-crisis } \\
\text { Just their profit reduced } \\
\text { Going holidays but do not pay our } \\
\text { salaries } \\
\text { We face economical problems } \\
\text { They do not care about these }\end{array}$ & $\begin{array}{c}\text { Employees looking for Equity } \\
\text { They feel a form of social } \\
\text { inequality }\end{array}$ & Equity \\
\hline $\begin{array}{l}\text { Personal responsibility for the } \\
\text { outcome } \\
\text { Can accomplish from start to finish } \\
\text { Job that requires knowledge and } \\
\text { skills } \\
\text { Independence work } \\
\text { Autonomy }\end{array}$ & $\begin{array}{l}\text { Responsibility } \\
\text { Knowledge and Skills } \\
\text { Independence } \\
\text { Variance/interesting job }\end{array}$ & $\begin{array}{l}\text { Job } \\
\text { characteristics } \\
\text { as intrinsic } \\
\text { motivation } \\
\text { quality within } \\
\text { the work }\end{array}$ \\
\hline $\begin{array}{l}\text { Fair balance work/personal life } \\
\text { Freedom of initiative } \\
\text { Correlation rewards/personal targets } \\
\text { Support and understanding to } \\
\text { employee's needs } \\
\text { I want to face me honestly... }\end{array}$ & $\begin{array}{l}\text { Working conditions } \\
\text { Relationships between } \\
\text { employees }\end{array}$ & $\begin{array}{l}\text { Working } \\
\text { environment }\end{array}$ \\
\hline $\begin{array}{l}\text { Improve myself every day } \\
\text { Develop within the work everyday } \\
\text { Exploit my scientific knowledge } \\
\text { Gain experience - expand my } \\
\text { knowledge } \\
\text { Refresh existing knowledge }\end{array}$ & $\begin{array}{c}\text { Continue working on my } \\
\text { profession } \\
\text { Develop my knowledge }\end{array}$ & $\begin{array}{l}\text { Professional } \\
\text { development }\end{array}$ \\
\hline \multicolumn{3}{|c|}{ Money as Motivators } \\
\hline $\begin{array}{l}\text { Demanding nature of the job } \\
\text { Mean to achieve to an end } \\
\text { Importance of money recognised } \\
\text { Motivation found from other sources }\end{array}$ & $\begin{array}{l}\text { Money as a primary motivator } \\
\text { Money as a second order } \\
\text { motivator }\end{array}$ & $\begin{array}{c}\text { Overall } \\
\text { motivational } \\
\text { Effect of money }\end{array}$ \\
\hline
\end{tabular}

Moreover, financial rewards did not prove to be among the top motivators for the employees during the economic crisis. It was stated many times that when other aspects are in order, money has very little motivational impact in the specific environment. The money incentive replaced a (possible) fixed monthly compensation of the employee.

\section{Proposals to Management}

As proposed management measures that will strengthen the specific motivation factors suggested the followings: 
- Verbal praises, that emphasize the appreciation of the employee work offered. Developing a climate of collaboration between management and employees and mutual support and appreciation.

- Working environment, where calm and good relations between colleagues predominate.

- Manager supportive and understanding of the employee personal / family problems of employees.

- A sense of security in the workplace (as far as feasible).

- Opportunities for progress and development / education. Organizing internal seminars where the existing knowledge in the organization will spread between older and younger employees and the team's working relationships will become stronger.

- Open communication and interaction with the organization's management. Organizing meetings and discussing the latest developments.

- Organization of social events within the firm will stimulate links between management and employees.

\section{Leadership During Economic Crisis}

Based on the results of the above research we couldn't describe the perfect Leader during the economic crisis as a Transactional or Transformational or Spiritual Leader but we conclude that he needs a personality who will:

- Inspire and motivate them

- Make them feel secure and safe at the workplace (satisfying the need of belonging)

- Communicate with them and discuss future plans and actions.

- Support them and try to understand the day by day problems and difficulties

- Appreciate their work

- Give them opportunities to develop their skill (during the crisis).

This is the profile (based on the current research) and the small contribution of this study to the description of the Crisis Leader.

\section{Discussion}

\subsection{Limitations of Current Research and Recommendations for Future Research}

The current research has several limitations. The first limitation regards the role of the researcher during the field work and the potential impact in the research process. A second limitation is that research took place in the setting of a time and place employees group that may differ in terms of purpose and structure from other workgroups. The findings are not easily transferable to other settings although they could offer useful insights in studying employee motivation, in general. This last limitation produces a recommendation for future research to include additional employees groups in the single study. The comparison between different workgroups could enable a more fruitful exploration of the role of motivation. A third limitation regards issues like power relations that are not addressed in the study. Future research should explicitly take them into consideration since power relations could further 
enhance our understanding of motivation in workplace (Zanoni et al., 2010).

\subsection{Contribution of the Study}

The current study attempts to make a contribution in the field of motivation in workplace. Taking into consideration the suggestions of several scholars (Hitka and Sirotiakova / 2011, Hitka and Balazova / 2015, Zavadsky et al / 2015), who point out the need for additional research on employee motivation in the workplace. The research findings position the present study along other studies in the literature that emphasize the multiple character of motivation.

\section{References}

Adam, S. J. (1963). Towards an understanding of inequity. Journal of Abnormal and Social Psychology, 67, 422-436. https://doi.org/10.1037/h0040968

Balourdos, D. (2013). The Social Portrait of Greece. National Centre for social research.

Charmaz, K. (2000). "Grounded Theory: Objectivist and constructivist methods: In the handbook of Qualitative Research". Edited by: N. K. Denzin \& Y. Linkoln.

Charmaz, K. (2006). Constructing Grounded Theory: A practical guide through Qualitative analysis. Sage Publication.

Chatzopoulou, M., Vlacvei, A., \& Monovasilis, T. (2015). Employee's Motivation and Satisfaction in light of Economic Crisis: Evidence of Grevana Prefecture-Greece. Procedia Economics and Finance, 24, 136-145. https://doi.org/10.1016/S2212-5671(15)00633-4

Deci, E. L. (1975). Intrinsic motivation. New York: Plenum. https://doi.org/10.1007/978-1-4613-4446-9

Glasser, G. B., \& Straus, L. A. (1967). The discovery of grounded theory. Strategies for Qualitative research. Addline Transition.

Grammatikopoulos, I., Koupidis, S., Moralis, D., Sadrazamis, A., Athinaiou, D., \& Giouzepas, I. (2013). Job motivation factors and performance incentives as efficient management tools: A study among mental health professionals, Archives of Hellenic Medicine/Arheia Ellenikes Iatrikes.

Herzberg, F. (1966). Work and the nature of man. Cleveland: World Publishing.

Hitka, M., \& Sirotiakova, M. (2011). The impact of the economic crisis on change in motivation of furniture company employees-case study.

Hitka, M., \& Balazova, Z. (2015). The impact of age, eructation and seniority on motivation of employees. Verslas: Praktika/Business: Theory and Practice, 16(1), 113-120. https://doi.org/10.3846/btp.2015.433

Hitka, M., Zavadska, Z., Jelasic, D., \& Balazova, Z. (2015). Qualitative Indicators of Employee Satisfaction and their Development in a particular period of time. https://doi.org/10.5552/drind.2015.1420 


\section{Macrothink}

International Journal of Human Resource Studies ISSN 2162-3058 2020, Vol. 10, No. 2

Jelasic, D. (2011). Motivating of Wood company processing and furniture manufacturing companies' employees in time of economic crisis. Human Resources management and Economics and ICT Volume V1, 2011.

Latham, G. P. (2012). Work motivation: History, theory, research, and practice. Sage Publications. https://doi.org/10.4135/9781506335520

Markovits, Y., Boer, D., \& Van Dick, R. (2013). Economic crisis and the employee: The effects of economic crisis on employee job satisfaction, commitment, and self regulation. European management Journal. https://doi.org/10.1016/j.emj.2013.09.005

Maslow, A. H. (1943). A theory of human motivation. Psychological review, 50(4), 370. https://doi.org/10.1037/h0054346

Matsaganis, M. (2013). The Greek crisis: social impact and policy responses Friedrich-Ebert-Stiftun. Available at www.fes.de/international/will

OECD (2010). Jobs for youth: Greece. Paris: Organisation for Economic Co-operation and Development.

Pagoulatos, G. (2003). Greece's New Political Economy: State, Finance and Growth from Postwar to EMU, London and New York: Palgrave Macmillan.

Stathakis, G. (2008). The fiscal crisis of the Greek economy. A historical view. Sychrona Themata, 108, 5-9.

Technical Chamber of Greece (TEE). (2008). The characteristics of the Greek Engineers employment. TEE Publication.

Tsekos, T. N. (2015). Structural Changes and Administrative Reform. The Political Portrait of Greece. Crisis and the deconstruction of the political, National Center of Social Research, Gutenberg Publications, Athens, 359-377. https://doi.org/10.2139/ssrn.2724439

Zavadsky, J., Hitka, M., \& Potkany, M. (2015) Changes of employee motivation of Slovak enterprises due to Global Economic Crisis. Business administration and Management XVIII. Gower publication. https://doi.org/10.15240/tul/001/2015-1-005

\section{Copyright Disclaimer}

Copyright for this article is retained by the author(s), with first publication rights granted to the journal.

This is an open-access article distributed under the terms and conditions of the Creative Commons Attribution license (http://creativecommons.org/licenses/by/4.0/). 